\title{
Pengembangan Instrumen Penilaian Model Two-Tier Multiple Choice Question (TTMCQ) di tingkat SMP Kabupaten Jepara pada Materi Panca Dharma
}

\author{
Mirrah Megha Singamurti \\ STAB Negeri Raden Wijaya Wonogiri, Jawa Tengah \\ mirrahmegha99@gmail.com
}

\begin{abstract}
Abstrak
Penelitian ini bertujuan untuk 1) mengembangkan instrumen penilaian Two-Tier Multiple Choice Question yang layak digunakan pada materi Pancadharma. Penelitian ini dilakukan menggunakan metode R\&D menggunakan langkah-langkah dari Borg and Gall. Lokasi penelitian dilakukan di SMP di kabupaten Jepara. Pengumpulan data dalam penelitian ini menggunakan angket, tes, wawancara dan dokumentasi. Hasil Penelitian ini diperoleh hasil bahwa Instrumen penilaian Two Tier Multiple Choice Question (TTMCQ) materi Pancadharma yang dikembangkan dikatakan layak dan memenuhi kriteria sebagai soal yang baik.
\end{abstract}

Kata Kunci : Penelitian Pengembangan, Instrumen Penilaian, Two-Tier Multiple Choice Question, Panca dharma

\begin{abstract}
This study aims to develop a Two Tier Multiple Choice Question Assessment instrument that is suitable for use in Pancadharma material. This reseacrh was conducted using the R\&D method using steps from Borg and Gall. The location of the study was conducted at Junior High School in Jepara Regency. Data collection in this study used questionnaires, test, interviews and documentation. The results of this study were obtained from the results. The results of the Two-Layer Multiple Choice Questions (TTMCQ) Study of Panca Dharma material developed fulfilled the criteria and fulfilled the criteria according.
\end{abstract}

Keywords : Assessment Instruments, Two Tier Multiple Choice Question, Panca Dharma, Religious Education.

\section{Pendahuluan}

Proses pendidikan merupakan kegiatan sosial atau pergaulan antara pendidik dan peserta didik dengan menggunakan isi atau materi pendidikan, metode dan alat pendidikan tertentu yang berlangsung dalam suatu lingkungan untuk mencapaian tujuan pendidikan yang telah ditetapkan. Kualitas pendidikan sangat ditentukan oleh kemampuan satuan pendidikan dalam mengelola proses pembelajaran. Salah satu kualitas dari pelaksanaan tugas keguruan, dapat dilihat dari hasil proses yang dilaksanakannya. Komponen mengajar maupun mendidik, melatih dan membimbing, tidak terpisahkan dengan tiga komponen penting sebagai hasil dari pendidikan, berupa pengetahuan, keterampilan dan sikap. Ketiga komponen hasil belajar tersebut dapat diketahui melalui komponen menilai dan mengevaluasi. Kesemua komponen tersebut terkait dengan kompetensi guru, dalam pelaksanaan tugasnya. Guru dalam pelaksanaan tugas, khususnya untuk pendidikan agama Buddha 
masih terdapat permasalahan terkait dengan pemahaman dengan keterbatasan informasi dan pengembangan diri guru, terbatasnya kegiatan pengembangan diri, sehingga berakibat kesulitan dan keterbatasan dalam pengembangan bahan ajar. Selain itu berakibat pula terhadap pemahaman guru pendidikan agama Buddha, dalam aplikasi model penilaian dari materi bahan ajar, yang tidak berkembang.

Penilaian merupakan bagian yang penting dalam proses pembelajaran. Dengan melakukan penilaian, pendidik sebagai pengelola kegiatan pembelajaran dapat mengetahui kemampuan yang dimiliki peserta didik, ketepatan metode mengajar yang digunakan dan keberhasilan peserta didik dalam meraih kompetensi yang ditetapkan. Dalam pelaksanaan menilai dan mengevaluasi, didalam komponen penilaian terkait dengan aspek penilaian pengetahuan yang merupakan aspek penting dan menjadi tolok ukur kemampuan siswa dalam memahami materi atau kompetensi yang diajarkan.

Penilaian dalam proses pembelajaran digunakan sebagai untuk mendeteksi kesulitan belajar (assesment as learning), penilaian sebagai proses pembelajaran (assessment for learning), dan penilaian sebagai alat untuk mengukur pencapaian dalam proses pembelajaran (assessment of learning). Melalui penilaian tersebut diharapkan peserta didik dapat menguasai kompetensi yang diharapkan. Untuk itu, digunakan teknik penilaian yang bervariasi sesuai dengan kompetensi yang akan dinilai, yaitu testulis, lisan, dan penugasan.

Model penilaian pendidikan agama buddha masih terbatas pada tes tertulis, tes lisan dan penugasan atau proyek, guru belum mengembangkan instrumen pengembangan yang lain, sehingga untuk memaksimalkan hasil dari penilaian dibutuhkan instrumen evaluasi yang dapat mengungkap pengetahuan yang dimiliki peserta didik secara mendalam tanpa takut adanya subjektivitas penilaian dan juga dapat mengurangi tindakan curang siswa dalam menjawab, untuk itu dibutuhkan instrumen yang sesuai.

Instrumen pilihan ganda hanya dapat menilai konten pengetahuan tanpa mempertimbangkan alasan dibalik pilihan tersebut. Sebagai perbaikan dari hal ini dikembangkan suatu instrumen pilihan ganda yang mencakup respon dan laternatif konsepsi siswa. Siswa diharuskan untuk membenarkan pilihan jawaban mereka dengan memberikan alasan. Penggunaan alasan ketika menjawab item tes pilihan ganda menjadi cara yang sensitif dan efektif untuk menilai pembelajaran yang bermakna. Hal positif temuan yang terkait dengan alasan siswa menyebabkan perkembangan tes diagnostik pilihan ganda dua tingkat (Two Tier Multiple Choice Question) yang bertujuan khusus untuk mengidentifikasi alternatif konsepsi siswa dalam konten yang jelas dan terbatas. Adodo (2013) menjelaskan bahwa Two-tier Multiple Choice (TTMC) adalah bentuk pertanyaan yang lebih canggih dari pertanyaan pilihan ganda. Tingkat pertama menyerupai pilihan 
ganda tradisional, yang biasanya berkaitan dengan pernyataan pengetahuan. Tingkat kedua menyerupai format dari soal pilihan ganda tradisional tetapi bertujuan untuk mendorong pemikiran dan penalaran.

Pendidikan Agama Buddha masih belum banyak adanya pengembangan penilaian sebagai evaluasi hasil belajar siswa guru masih terbatas menggunakan pilihan ganda atau uraian belum adanya pengembangan penilaian dengan cara yang lain, salah satu materi dalam pendidikan agama buddha yang perlu adanya penekanan pemahaman yaitu materi Panca Dharma, materi panca dharma menekankan pemahaman dan aplikasi siswa kepada lingkungan masyarakat, karena siswa harus mengaplikasikannya dalam masyarakat yang lebih luas agak menjadi manusia yang bisa di terima dan menjadi contoh yang baik di lingkungan masyarakat tempat tinggal. Salah satunya di kabupaten Jepara, kecamatan Keling dimana masyarakat yang tinggal disana banyak terdapat umat buddha, sehingga sangat perlu penilaian evaluasi hasil belajar siswa untuk mengetahui pemahaman dari konsep dan aplikasi dalam keseharian sebagai bukti dalam pemahaman terhadap materi panca dharma, karena materi panca dharma sangat erat kaitannya dengan lingkungan masyarakat.

Berdasarkan uraian diatas perlu adanya pengembangan instrumen penilaian Two-Tier Multiple Choice Question (TTMCQ) di tingkat Sekolah Menengah Pertama di kabupaten Jepara.

\section{Metode Penelitian}

Penelitian dan pengembangan (R\&D) adalah proses yang digunakan untuk mengembangkan dan memvalidasi produk pendidikan. Langkah dalam proses ini biasanya merujuk pada siklus R\&D yang terdiri dari mempelajari temuan penelitian untuk kemudian mengembangkan produk, mengembangkan produk berdasarkan temuan penelitian, uji lapangan dimana produk itu akan digunakan nantinya, dan merevisi produk untuk memperbaiki kekurangan yang ditemukan pada uji lapangan. Dalam siklus $R \& D$ ini akan berulang sampai produk yang dikembangkan sesuai dengan tujuan yang telah ditetapkan (Borg dan Gall, 1983: 624).

Langkah utama dalam siklus R\&D yang digunakan untuk mengembangkan produk adalah sebagai berikut (Borg dan Gall, 1983:624-625):

a) Perencanaan (Planning)

Perencanaan merupakan aspek paling penting dari penelitian yang berbasis produk pendidikan yang merupakan pernyataan tujuan spesifik yang akan dicapai dari produk yang akan dikembangkan.

b) Pengembangan bentuk awal produk (Develop of the preliminary form of the product)

Pada langkah ini akan dikembangkan produk awal yang dadasari dari hasil angket dan wawancara. Langkah ini merupakan suatu prinsip yang penting yang harus diamati dalam pengembangan produk bentuk awal sehingga 
memungkinkan mendapatkan banyak masukan dari uji lapangan.

c) Uji lapangan awal dan revisi (Preliminary field test and product revision)

Tujuan dari tahap ini adalah untuk mendapatkan evaluasi kuantitatif awal dari produk pendidikan yang baru. Sehingga hasilnya bisa digunakan sebagai acuan revisi produk.

d) Uji lapangan utama dan Revisi (Main field test and product revision)

Tujuan dari siklus tahap ini adalah untuk menentukan apakah produk yang sedang dikembangkan peformanya memenuhi tujuannya. Hasil dari uji ini digunakan sebagai landasan untuk merevisi produk

e) Uji pelaksanaan lapangan dan revisi (Operational field test and final product revison)

Tujuan dari tahap ini adalah untuk menentukan produk pendidikan telah benar-benar siap untuk digunakan di sekolah tanpa kehadiran pengembang dan stafnya. Hasil dari uji ini digunakan sebagai saran dan masukan untuk penyempurnaan produk yang dikembangkan

f) Diseminasi dan Implementasi (Dissemination and implementation)

Diseminasi merupakan cara yang efektif untuk menjustifikasi dengan mendemostrasikan produk hasil penelitian dan pengembangan kepada khalayak.

Skala kecil akan dilaksanakan dengan melibatkan 1 orang guru pendidikan agama buddha serta 3 Mahasiswa dari STAB Negeri
Raden Wijaya Wonogiri. Skala Menengah akan dilaksanakan dengan melibatkan siswa kelas VII sebanyak 5 siswa dari SMP Negeri 1 Keling. Skala Meluas akan dilaksanakan dengan melibatkan siswa kelas VII sebanyak 10 yang terbagi dari 10 siswa dari SMP Negeri 2 keling. Pertimbangan menggunakan kelas VII karena materi Panca Dharma disampaikan di kelas VII.

Informan dalam penelitian ini terdiri dari ahli atau pakar, peserta didik serta guru. Ahli atau pakar dipilih berdasarkan pada kompetensi dalam bidangnya dan memiliki kredibilitas untuk menjadi sumber data. Sekolah yang dipilih merupakan sekolah dengan kriteria baik berdasarkan input peserta didik maupun rentang nilai yang di capai berdasarkan mata pelajaran pendidikan agama buddha dengan jumlah 2 sekolah.

Teknik dan pengumpulan data yang digunakan dalam penelitian ini antara lain:

1. Angket

Dalam penelitian ini angket untuk peserta didik digunakan untuk memperoleh data tentang masukan terkait dengan instrumen TTMCQ. Hasil data yang diperoleh digunakan sebagai dasar melakukan revisi produk jika diperlukan, sehingga hasil produk setelah dilakukam uji coba benarbenar sesuai digunakan dalam pembelajaran.

2. Lembar Wawancara

Lembar wawancara menurut Sugiyono (2012:137) digunakan sebagai studi pendahuluan untuk menemukan permasalahan yang akan diteliti. Dalam 
penelitian ini wawancara digunakan sebagai alat pengumpul data sehubungan dengan informasi kondisi awal dan analisis kebutuhan.

3. Tes

Tes digunakan untuk mengukur kemampuan siswa. Dalam penelitian ini tes dilakukan dengan menggunakan instrumen Two-Tier Multiple Choice Question (TTMCQ)

Sedangkan untuk teknik analisis data menggunakan valditas isi dimana dalam penelitian ini menggunakan validasi isi dari ahli yang dianalisis dengan menggunakan formula Aiken. Selanjutnya dilakukan pengujian reliabilitas menggunakan formula Alpha Cronbach, dalam penelitian ini dilakukan pula analisis daya beda item yang digunakan untuk melihat besar kecilnya angka indeks diskriminasi item, dalam penelitian ini menggunakan indeks diskriminasi (daya pembeda), dalam penelitian ini dilakukan uji tingkat kesukaran atau difficullty index, dengan menggunakan rumus yang dikemukakan oleh Du Bois.

\section{Hasil Penelitian dan Pembahasan}

Penelitian ini dimulai dengan melaksanakan uji pendahuluan (premilinary study) di sekolah tahap uji pendahuluan dimaksudkan untuk menganalisis kebutuhan (need assessment) di lapangan, sehingga produk yang dikembangkan benar-benar berasal dari kebutuhan yang ada di lapangan. Uji pendahuluan dilaksanakan dengan melakukan wawancara dengan guru dan siswa mata pelajaran Pendidikan Agama Buddha. Hasil dari uji pendahuluan yang dilakukan diperoleh hasil bahwa guru belum banyak melakukan inovasi untuk pembelajaran baik dari perencanaan, pelaksanaan dan evaluasi. Masih terbatas untuk pelatihan dalam pengembangan dalam pembelajaran sehingga masih sangat sedikit pengembangan yang dilakukan oleh guru. Guru juga menjelaskan bahwa evaluasi pembelajaran yang dilakukan belum dilakukan pengembangan dalam hal ini hanya terbatas pada soal essay dan pilihan ganda. Belum adanya pelatihan ataupun contoh soal yang lain membuat guru kesulitan dalam melakukan pengembangan dalam pembelajaran.

\section{a. Pengembangan Produk}

Pengembangan produk dalam penelitian ini yaitu pengembangan instrument penilaian menggunakan model Two Tier Multiple Choice Question (TTMCQ) pada materi Pancadharma. Materi yang terkandung didalamnya yaitu membahas tentang Metta karuna, Samma ajiva, Kamasavara, Sacca, Sati sampajana serta penerapannya dalam kehidupan sehari-hari. Dalam penelitian ini dilakukan pengembangan instrument pembelajaran, dimana instrument pembelajaran yang dikembangkan yaitu alat evaluasi yang dipakai, dalam penelitian ini mengembangkan model penilaian Two Tier Multiple Choice Question dimana dalam penilaian tersebut terdapat dua jenis soal yaitu soal utama dan soal alasan, soal utama berisikan materi pokok yang berkaitan dengan indikator yang telah dibuat, sedangkan soal 
alasan berisikan alasan yang mendukung jawaban soal utama, dimana alasan ini harus berkaiatan dengan setiap soal utama yang ada. Desain awal penilaian yang dibuat berjumlah 15 soal tipe TTMCQ

\section{b. Penyusunan Draf Produk}

Dari hasil pencarian informasi melalui hasil studi pustaka, hasil wawancara dengan guru dan sisswa dibuat produk penelitian pengembangan instrumen penilaian menggunakan model Two Tier Multiple Choice Question dengan menggunakan materi Pancadharma, evaluasi yang digunakan yaitu pada dasarnya masih menggunakan pilihan ganda tetapi merupakan pilihan ganda bertingkat, dimana soal tersebut terdapat soal utama dan alasan.

Dalam evaluasi ini dapat diketahui siswa memahami konsep atau tidak, karena tidak hanya soal pilihan ganda saja tetapi terdapat alasan yang dapat memperkuat jawaban soal utama. Jika siswa memiliki pengetahuan yang kuat terhadap materi maka dapat diketahui tidak hanya merupakan hafalan saja. Pengetahuan yang dimiliki terkait materi juga akan dapat diketahui, seberapa paham siswa dalam memperlajari materi yang dijelaskan guru pun akan sangat terlihat.

Hasil dari tahap pemeriksaan pendahuluan penelitian guru hanya menggunakan soal evaluasi berupa soal model essay dan pilihan ganda. Namun soal pilihan ganda masih kurang efektif untuk mengetahui kemampuan pemahaman yang dimiliki oleh siswa, sedangkan soal essay atau uraian membutuhkan waktu yang lama dalam pelaksanaan dan pengoreksiannya.

Berdasarkan hal tersebut dalam penelitian ini instrument yang dipilih Two-Tier Multiple Choice Question. Bentuk soal ini merupakan jenis soal dengan pilihan jawaban utama disertai dengan alasan.

Langkah pertama merencanakan tujuan tes yaitu sebagai intrumen penilaian formatif, untuk memperoleh masukan tentang keberhasilan pelaksanaan pembelajaran, dimana masukan tersebut akan berguna untuk memperbaiki strategi dalam pembelajaran.

Langkah kedua merumuskan lingkup materi tes tentang pancadharma dimana materi tersebut erat kaitannya dengan materi sila terutama Pancasila buddhis yang ada, dalam materi pancadharama harus berisikan tentang Metta Karuna, Samma Ajiva, Kamasavara, Sacca, Sati Sampajanna dimana kesemua materi tersebut berkaiatan dengan kehidpan sehari-hari.

Langkah ketiga yaitu menentukan kompetensi yang akan diuji atau indicator yang akan diuji disesuaikan dengan indicator yang akan dicapai. Sekaligus penyusunan kisikisi dengan materi yang ada dengan tipe soal, karena tipe soal utama dengan tipe soal alasan berlainan.

Langkah terakhir yaitu pengembangan draf instrument, dimana soal yang dibuat disesuaikan dengan idnkator soal yang telah dibuat sebelumnya. Dimana penulisan soal adalah penjabaran indicator menjadi pertanyaan-pertanyaan yang dikarakteristiknya sesuai dengan pedoman kisi-kisi. Penskoran 
model soal two-tier test yang akan disajikan dalam tabel1

Tabel 1. Skoring soal Two Tier Multiple Choice Question

\begin{tabular}{|l|l|l|}
\hline No & Aspek Penilaian & Skor \\
\hline 1 & Tidak menjawab (TJ) atau & 0 \\
& jawaban salah-alasan salah (SS) & \\
2 & Jawaban salah-alasan benar (SB) & 1 \\
3 & Jawaban benar-alasan salah (BS) & 2 \\
4 & Jawaban benar-alasan benar (BB) & 3 \\
\hline
\end{tabular}

\section{c. Uji Coba Draft Produk}

a) Uji Validitas

Validitas dilakukan oleh 3 orang ahli dalam evaluasi. Dalam penelitian ini, validator butir soal dilakukan oleh Suharno, M.Pd.B selaku dosen agama Buddha mengajar Kitab Suci Agama Buddha Sutta Pitaka, Ari Mariyono, M.Pd sebagai dosen Pokok-Pokok Dasar Agama Buddha, Kiswati, S.Ag sebagai guru pengajar agama Buddha di SMP Negeri 1 Keling dan SMP Negeri 2 Keling Kabupaten Jepara serta 5 mahasiswa dari Sekolah Tinggi Agama Buddha Negeri Raden Wijaya Wonogiri Semester 6 yang sudah menempuh PPL (Praktik Mengajar).

b) Hasil Uji Coba Draf Produk

Hasil validasi yang telah dilakukan digunakan sebagai dasar revisi penilaian pembelajaran. Validasi yang dilakukan menggunakan validasi Aiken. Validasi isi dilakukan oleh 2 orang ahli terwakili dari dosen agama Buddha dan guru agama Buddha serta 5 mahasiswa dari STAB Negeri Raden Wijaya Wonogiri Jawa 42
Tengah. Adapun hasil uji validasi draf produk penilaian diperoleh nilai validasi 0,9222 dengan persentase validasi isi 92,22\% yang dapat disimpulkan Layak untuk dipergunakan (Baik).

\section{d. Pengujian Produk}

Produk yang telah dikembangkan dilakukan beberapa kali uji coba. Uji coba dilakukan sebanyak tiga tahap, yaitu uji coba skala terbatas, uji coba skala menengah dan uji coba skala luas. Tiga uji coba yang telah dilakukan diperoleh hasil sebagai berikut:

1) Uji Coba Skala Terbatas

Uji coba skala terbatas bertujuan untuk mengetahui keterbacaan penilaian Two Tier Multiple Choice Question. Sampel untuk keterbacaan di berikan kepada guru dan calon pendidikan disini peneliti melibatkan 5 mahasiswa STAB Negeri Raden Wijaya jurusan Dharmacarya program studi Pendidikan Keagamaan Buddha untuk menilai instrumen penilaian TTMCQ dengan materi Pancadharma. Dilakukan pengujian ini dengan tujuan supaya dapat memberikan masukan terkait dengan materi sekaligus mengetahui kesesuaian penilaian dengan aturan yang ada. 5 mahasiswa dipilih secara acak, hasil uji coba skala terbatas ini digunakan sebagai dasar untuk revisi awal.

2) Uji Coba Skala Menengah

Uji coba skala menengah bertujuan untuk mengetahui karakteristik produk penilaian TTMCQ yang dibuat. Sampel 
untuk uji coba skala menengah adalah siswa kelas VII baik di SMP Negeri 1 Keling. Hasil dari uji skala menengah ini digunakan sebagai dasar untuk merevisi penilaian TTMCQ yang telah dibuat, yang nantinya akan dipergunakan untuk analisis butir soal dan uji keberlanjutan. Pada uji coba skala menengah penilaian yang dikembangkan sudah dapat diaplikasikan untuk uji coba skala luas. Hasil masukan yang diberikan yaitu waktu mengerjakan soal terlalu singkat sehingga perlu ditambahkan waktu dalam pengerjaan soal.

Adapun hasil pengujian soal TTMCQ pada uji coba skala menengah sebagai berikut:

a) Reliabilitas

Pengujian reliabilitas dalam penelitian ini menggunakan alpha yang tertera pada iteman. Adapun hasil pengujian reliabilitas soal two tier test secara keseluruhan pada uji coba skala menengah disajikan pada tabel berikut:

Tabel 2. Hasil Perhitungan Reliabilitas Skala Menengah

\begin{tabular}{|l|c|}
\hline Uji Coba Skala Menengah & Nilai \\
\hline Firsh Tier & 0,754 \\
Second Tier & 0,826 \\
\hline
\end{tabular}

Pengujian reliabilitas soal hanya dilakukan pada pengujian skala menenegah. Hal ini dengan tujuan dari masing-masing uji coba, dimana uji coba skala menengah digunakan untuk mengetahui karakteristik produk yang dibuat sehingga perhitungan karakteristik soal hanya dilakukan pada hasil pada uji coba skala menengah.

Berdasarkan hasil pengujian reliabilitas soal TTMCQ tersebut, reliabilitas yang dihasilkan yaitu $r>0,700$. Hal ini berarti bahwa soal TTMCQ yang diujikan dapat dikatakan reliabel sehingga memiliki tingkat keajegan atau konsistensi yang baik.

b) Tingkat kesukaran

Pengujian tingkat kesukaran menggunakan software Iteman. Tingkat kesukaran soal menunjukkan sukar atau tidaknya butir soal, dimana tingkat kesukuran dilihat dari peluang siswa menjawab benar pada tingkat kemampuan tertentu. Adapun hasil pengujian tingkat kesukaran soal TTMCQ sebagai berikut:

Tabel 3. Persentase Tingkat Kesukaran Soal

\begin{tabular}{|l|l|l|l|}
\hline \multirow{2}{*}{$\begin{array}{l}\text { Tingkat } \\
\text { Kesukaran }\end{array}$} & \multicolumn{3}{|c|}{ Persentase (\%) } \\
\cline { 2 - 4 } & Mudah & Cukup & Sukar \\
\hline First Tier & 40 & 53,33 & 6,67 \\
Second Tier & 60 & 33,33 & 6,67 \\
\hline
\end{tabular}

c) Daya Beda

Daya beda soal adalah kemampuan suatu butir soal untuk dapat membedakan siswa kelompok atas (siswa dengan skor tinggi) dengan kelompok bawah (siswa dengan skor rendah). Suatu butir soal dikatakan baik jika harga indeks bedanya bernilai positif, apabila indeks daya beda soal bernilai negatif, hal ini berarti bahwa jumlah siswa kelompok bawah lebih banyak menjawab benar dibandingkan dengan siswa kelompok atas yang 
menjawab benar pada butir soal tersebut.

Adapun hasil pengujian daya beda soal pada indeks uji coba skala menengah disajikan pada tabel berikut:

Tabel 4. Hasil Pengujian Daya Pembeda Soal

\begin{tabular}{|l|l|c|c|c|l|}
\hline \multirow{2}{*}{ Soal } & \multirow{2}{*}{ Item } & \multicolumn{4}{|c|}{$\begin{array}{l}\text { Persentase Daya Beda Soal } \\
(\boldsymbol{\%})\end{array}$} \\
\cline { 3 - 6 } & & $\mathbf{J}$ & $\mathbf{C}$ & $\mathbf{B}$ & BS \\
\hline First & 15 & 13,33 & 13,33 & 66,67 & 6,67 \\
$\begin{array}{l}\text { Seco } \\
\text { nd }\end{array}$ & 15 & 0 & 26,67 & 46,66 & 26,67 \\
\hline
\end{tabular}

3) Uji Coba Skala Luas

Uji coba skala luas bertujuan untuk mengetahui efektifitas dan fleksibilitas produk akhir. Serta mendapatkan tanggapan tentang layak tidaknya instrumen tersebut digunakan dalam proses pembelajaran, serta mengetahui kerbelakukan instrumen yang dikembangkan. Uji coba skala luas dilaksanakan di SMP Negeri 2 Keling di siswa kelas VII dengan materi Pancadharma.

\section{1) Analisis Kualitas Soal}

Analisis kualitas soal diperlukan untuk mengetahui kualitas soal yang dikembangkan. Analisis kualitas soal dilakukan berdasarkan pada hasil uji coba soal. Uji coba soal perlu dilakukan sebelum mengujikan soal dalam tes yang sebenarnya, dimana hasil uji coba soal memberikan informasi atau data empirik tentang kebaikan soal yang dikembangkan (Mardapi, 2012). Berdasarkan hasil uji coba soal dapat diketahui: validitas, reliabilitas, daya pembeda dan tingkat kesukaran soal yang dikembangkan. Suatu soal dapat dikatakan sebagai soal yang baik apabila memenuhi kriteria validitas, reliabilitas, daya pembeda, tingkat kesukaran sebagai soal yang baik.

Uji Validasi yang digunakan adalah validitas isi, dimana nilai $\mathrm{V}$ berkisar antara 0 - 1 dan suatu butir soal dikatakan valid secara isi apabila memiliki harga $\mathrm{V}$ yaitu 0,9222 untuk jumlah penilai (raters) 8 orang (Aiken, 1985). Berdasarkan uji validitas yang telah dilakukan dengan jumlah penilai (raters) 8 orang, soal twotier multiple choice question yang dikembangkan dengan jumlah 15 butir, 1 butir soal dengan nilai validasi $0,83333,1$ butir soal dengan nilai $0,875,8$ butir soal dengan nilai validasi $0,91667,5$ butir soal dengan nilai validasi 0,95833 , kesemua butir soal dinyatakan valid, tetapi dari soal tersebut terdapat masukan dari penilai sehingga dilakukan perbaikan.

\section{2) Hasil Analisis Uji Coba Produk}

a) Uji Coba Skala Terbatas

Uji coba skala terbatas dilakukan dengan mengujicobakan soal TTMCQ materi pancadharma kepada 5 mahasiswa. Dimana dilakukan uji coba skala terbatas ini adalah untuk mengetahui keterbacaan soal, yaitu apakah soal TTMCQ yang dikembangkan menggunakan bahasa yang mudah dipahami oleh mahasiswa atau sebaliknya dan mengetahui apakah waktu 
yang diberikan dirasa cukup untuk mengerjakan soal yang diberikan. Hasil dari uji skala terbatas ini digunakan sebagai dasar untuk merevisi butir soal untuk uji coba selanjutnya.

Uji coba skala terbatas dilaksanakan pada mahasiswa STAB Negeri Raden Wijaya Wonogiri Jawa Tengah dimana uji skala terbatas untuk mengetahui tanggapan untuk soal yang dikembangkan dapat disimpulkan sebagai berikut: hampir seluruh siswa peserta uji coba skala terbatas belum pernah mengerjakan soal dengan model TTMCQ. Namun dilihat dari soal yang diberikan, sebagaina besar mahasiswa menyatakan bahwa soal-soal yang diberikan cukup dapat dipahami, hanya pada beberapa soal terdapat data yang kurang lengkap dan terdapat beberapa soal yang tidak memiliki jawaban pada option yang diberikan, sehingga diperlukan beberapa perbaikan pada soal-soal tersebut. dilihat dari tingkat kesukaran soal, terdapat beberapa soal yang tergolong sukar sehingga dalam pengerjaannya membutuhkan waktu yang lebih lama dibandingkan dengan soal yang lain. Sedangkan dari segi waktu yang diberikan yaitu 30 menit dirasa cukup untuk mengerjakan 15 soal TTMCQ yang diberikan.

b) Uji Coba Skala Menengah

Tahap uji coba selanjutnya adalah uji coba skala menengah. Uji coba ini dilakukan dengan mengujikan soal two- tier ke satu kelas pada masing-masing sekolah. Dimana tujuan dari dilaksanakannya uji coba ini adalah untuk mengetahui karakteristik soal TTMCQ yang dikembangkan.

Suatu soal juga dapat dikatakan sebagai soal yang baik apabila memiliki sifat keajegan atau konstan, atau disebut juga reliabel. Reliabilitas atau keajegan suatu soal ditunjukkan dalam bentuk derajat keajegan yang bernilai antara 0-1. Dimana suatu soal dikatakan reliabel, apabila derajat keajegan minimal adalah 0,700. Hasil koefisien reliabilitas untuk soal utama (first tier) adalah 0,754 dan soal alasan (second tier) adalah 0,826. Hal ini berarti bahwa soal two-tier yang dikembangkan memiliki tingkat kesukaran yang baik (sesuai dengan tujuan yang diinginkan).

Tingkat kesukaran suatu butir soal berfungsi sesuai dengan tujuan dari tes. Dimana untuk soal TTMCQ yang dikembangkan ini berfungsi sebagai tes formatif, sehingga digunakan butir soal dengan proporsi tingkat kesukaran mudah, cukup dan sukar. Hasil pengujian tingkat kesukaran soal dari uji skala menengah yang telah dilakukan untuk soal utama (first tier) yaitu untuk kategori Mudah 40\%, Cukup 53,33\% dan Sukar 6,67 , sedangkan untuk soal alasan (second tier) untuk kategori Mudah 60\%, Cukup $33,3 \%$ dan Sukar $6,67 \%$ sehingga soal TTMCQ dikategorikan sebagai soal yang cukup. 
Salah satu syarat kriteria soal yang baik, selain dilihat berdasarkan reliabilitas dan tingkat kesukarannya, dilihat juga berdasarkan daya pembeda soal. Hasil perhitungan daya pembeda soal hasil uji coba skala menengah diperoleh bahwa daya pembeda soal, baik soal utama (first tier) maupun soal alasan (second tier) memiliki daya beda yang melebihi 0,2 berdasarkan Crocker dan Algina (dalam Yamtinah, 2009), dikatakan bahwa apabila suatu butir soal memiliki daya beda lebih dari 0,2 berarti bahwa soal dapat digunakan. Selain itu, daya pembeda soal seluruhnya bernilai positif, hal ini menandakan bahwa soal yang dikembangkan telah membedakan siswa kelompok atas (siswa skor tinggi) dengan siswa kelompok bawah (siswa dengan skor rendah). Hasil yang diperoleh dari daya pembeda soal untuk soal utama kategori soal Jelek 13,33\%, Cukup 13,33\%, Baik 66,67\% dan Baik Sekali $6,67 \%$ sedangkan untuk soal alasan kategori soal Cukup 26,67\%, Baik $46,66 \%$ dan baik Sekali $26,67 \%$ yang kesemuanya disimpulkan dari daya pembeda soal ini dikategorikan soal baik.

c) Uji Coba Skala Luas

Soal TTMCQ pada tahap ini diujikan kepada siswa kelas 7 di SMP Negeri 1 Keling dan SMP Negeri 2 Keling. Uji coba dilaksanakan sebanyak tiga kali. Dimana berdasarkan hasil perhitungan reliabilitas 15 butir soal yang dikembangkan dapat dikatakan layak digunakan karena memberikan harga 0,754

\section{Daftar Pustaka}

Adodo, S.O . 2013. Effect of Two-Tier Multiple Choice Diagnostic Assesment Items on Student's Learning Outcome in Basic Science Technology. Ondo State: Academic Journal of Interdisciplinary Studies by MCSERCEMAS-Sapienza University of Rome. E-ISSN 2281-4612. ISSN 2281-3993, Vol No. 2.

Aikenhead, G., S., 2005. Educacion Cuinica, 16,3

Arikunto, Suharsimi. 2006. Dasar-Dasar Evaluasi Pendidikan. Jakarta: PT. Bumi Aksara.

Borg and Gall. 1983. Education Research An Introduction. New York: Logman Inc.

Chandrasegaran, A.L., Treagust, D. F Mocerino, M. 2007. The Development of a Two-Tier Multiple-Choice Diagnostic Instrument for Evaluating Secondary School Student's Ability to Describe and Explain Chemical Reactions Using Multiple Level of Representation. The Royal Society of Chemistry: Chemistry Education Research and Practice, Vol 8. No. 3, $293-307$.

Depdiknas. 2003. Undang-Undang RI Nomor 20 tahun 2003 pasal 1 dan 3 tentang sistem pendidikan nasional.

Kemendiknas. 2003. Undang-Undang Republik Indonesia nomor 20 tahun 2003 tentang Sistem Pendidikan Nasional.

Musfiqon. 2012. Pengembangan Media dan Sumber Media Pembelajaran. Jakarta: PT Prestasi Pustakaraya

Nofiana. Mufida 2013. Pengembangan Instrumen Evaluasi Two-Tier Multiple Choice Question untuk Mengukur 
Jurnal Pendidikan, Sains Sosial dan Agama

Keterampilan Berpikir Tingkat Tinggi pada Materi Kingdom Plantae. Digilib UNS

Sugiyono. 2012. Metode Penelitian Pendidikan: Pendekatan Kuantitatif, Kualitatif dan R\&D. Bandung : Alfabeta

Tuysuz, Cengiz. 2009. Development of two tier diagnostic instrument and assess students understanding in chemistry. Scientific Research and Essay Vo; 4 (6) pp 626-631 